\title{
Imaging in Cushing's Syndrome
}

\begin{abstract}
Once the diagnosis of Cushing's syndrome (CS) has been established, the main step is to differentiate between ACTH dependent and independent disease. In adults, $80 \%$ of CS is due to ACTH-dependent causes and $20 \%$ due to adrenal causes. ACTHsecreting neoplasms cause ACTH-dependent CS. These are usually anterior pituitary microadenomas, which result in the classic Cushing's disease. Non-pituitary ectopic sources of ACTH, such as a small-cell lung carcinoma or carcinoid tumours, are the source of the remainder of ACTH-dependent disease. In the majority of patients presenting with clinical and biochemical evidence of CS, modern non-invasive imaging can accurately and efficiently provide the cause and the nature of the underlying pathology. Imaging is essential for determining the source of ACTH in ectopic ACTH production, locating the pituitary tumours and distinguishing adrenal adenomas, carcinomas and hyperplasias. In our chapter we review the adrenal appearances in ACTH-dependent and ACTH-independent CS. We also include a discussion on the use of MRI and CT for the detection and management of pituitary ACTH secreting adenomas. CT of the chest, abdomen and pelvis with intravenous injection of contrast medium is the most sensitive imaging modality for the identification of the ectopic ACTH source and detecting adrenal pathology. MRI is used for characterising adrenal adenomas, problem solving in difficult cases and for detecting ACTH-secreting pituitary adenomas. (Arq Bras Endocrinol Metab 2007; 51/8:1319-1328)
\end{abstract}

Keywords: Cushing's syndrome; Pituitary; Adrenal; Adenomas; Ectopic ACTH; Computerized tomography; Magnetic resonance imaging

\section{RESUMO}

Imagem em Síndrome de Cushing.

Uma vez estabelecido o diagnóstico da síndrome de Cushing (SC), o passo principal é diferenciar entre a doença ACTH-dependente e a independente. Em adultos, $80 \%$ da SC é devida a causas ACTH-dependentes e $20 \%$ a causas adrenais. Neoplasias secretoras de ACTH causam a SC ACTH-dependente: usualmente são microadenomas da hipófise anterior que resultam na clássica doença de Cushing. Fontes ectópicas (não hipofisárias) de ACTH, como o carcinoma pulmonar de células pequenas e tumores carcinóides, são a origem do restante da doença ACTHdependente. Na maioria dos pacientes que se apresentam com evidências clínicas e bioquímicas da SC, técnicas modernas de imagem não invasivas podem apontar acurada e eficientemente a causa e a natureza da patologia subjacente. A imagem é essencial para a determinação da fonte de ACTH na produção ectópica desse hormônio, na localização de tumores hipofisários e na distinção entre adenomas, carcinomas e hiperplasias adrenais. Nesse artigo revisaremos a imagem adrenal na SC ACTH-dependente e independente. Incluiremos, também, uma discussão sobre o uso da RM e da TC na detecção e manejo dos adenomas hipofisários secretores de ACTH. TC de tórax, abdome e pelve, com a injeção intravenosa de meio de contraste, é a modalidade de imagem mais sensível para a identificação da fonte ectópica de ACTH e na detecção da patologia adrenal. A RM é empregada para a caracterização de adenomas adrenais, para a solução de problemas em casos difíceis e para a detecção de adenomas hipofisários secretores de ACTH. (Arq Bras Endocrinol Metab 2007;51/8:1319-1328)

Descritores: Síndrome de Cushing; Hipófise; Adrenal; Adenomas; ACTH ectópico; Tomografia computadorizada; Ressonância magnética

\section{revisão}

\author{
ANJU SAHDEV \\ RODNEY H. REZNEK \\ JANE EVANSON \\ ASHLEY B. GROSSMAN
}

Department of Diagnostic

Imaging (AS \& JE), Institute of

Cancer, Cancer Imaging (RHR),

and Department of

Endocrinology (ABG), St.

Bartholomew's Hospital,

London, UK.

Recebido em 15/08/07

Aceito em 19/08/07 
C USHING'S SYNDROME is a multisystem disorder resulting from chronic exposure to inappropriately elevated concentrations of free circulating glucocorticoids. The commonest cause is exogenous administration of glucocorticoids, with endogenous causes being relatively rare with an approximate incidence of 13 new cases per million per year ( 1 ). The diagnosis of Cushing's syndrome is confirmed biochemically by measuring 24 hour urinary free cortisol, dexamethasone suppression tests and insulin tolerance tests. Once the diagnosis of Cushing's syndrome has been established, the main step is to differentiate between ACTH dependent and independent disease. In adults $80 \%$ of Cushing's syndrome is due to ACTH-dependent causes and $20 \%$ due to adrenal causes. However, in young children, adrenal causes predominate, particularly in the first decade of life (2). ACTH-secreting neoplasms cause ACTH-dependent Cushing's syndrome. These are usually anterior pituitary microadenomas which result in the classic Cushing's disease. Non-pituitary ectopic sources of ACTH, such as a small-cell lung carcinoma or carcinoid tumours are the source of the remainder of ACTH-dependent disease. ACTH-independent disease is usually due adrenal causes, most frequently primary adrenocortical adenoma or carcinoma. Bilateral micronodular and macronodular hyperplasia are uncommon causes of Cushing's syndrome. Rarely Cushing's syndrome is caused by include the McCune-Albright syndrome and food-dependent Cushing's syndrome. Cushing's syndrome due to any cause may be cyclical.

Distinguishing between ACTH dependent and independent disease requires a combination of biochemical and radiological investigations. The biochemical tests include plasma concentrations of ACTH, potassium and glucose, the corticotrophin releasing hormone and dexamethasone suppression tests, and tumour markers particularly peptides, $\beta$ human chorionic gonadotrophin and plasma carcinoembryonic antigen.

Imaging is essential for determining the source of ACTH in ectopic ACTH production, locating the pituitary tumours and distinguishing adrenal adenomas, carcinomas and hyperplasias.

\section{ACTH-DEPENDENT CUSHING'S SYNDROME: THE APPEARANCE OF ADRENAL GLANDS}

Having confirmed a biochemical diagnosis of ACTHdependent Cushing's, it is imperative to identify the source of ACTH production. Clinically and biochemically it may be difficult to distinguish between a pituitary or ectopic ACTH secreting tumour, some of which may be very small and difficult to locate. Chronic ACTH hyperstimulation of the adrenal glands usually results in bilateral enlargement evident on computed tomography (CT) and magnetic resonance imaging (MRI). The largest adrenal glands, usually nodular in outline, result from an ectopic rather than pituitary ACTH source. Two types of adrenal enlargement are seen pathologically and on CT: smooth (diffuse) or nodular (micronodular and macronodular) $(3,4)$. Smooth hyperplasia is more common than nodular hyperplasia, accounting for $83 \%$ of cases in one series (figure 1). In $30 \%$ of cases with histopathological hyperplasia, the adrenal glands appear normal on CT (3). A normal CT therefore does not exclude the diagnosis. Pathologically, nodular hyperplasia can be micro or macronodular. In macronodular hyperplasia there is bilateral enlargement of adrenal glands with one or more nodules visible on CT (figure 2). The definition of macronodular hyperplasia is arbitrary and on CT has been defined by Doppman et al. as multiple nodules greater than $6 \mathrm{~mm}$ (4). Nodular hyperplasia has been reported in $10-40 \%$ of patients with pituitary-dependent Cushing's syndrome, Cushing's disease $(4,5)$. A dominant nodule in nodular hyperplasia may reach up to $4 \mathrm{~cm}$ and can be misinterpreted as an apparently hyperfunctioning adenoma, conflicting with biochemical evidence of ACTHdependence. Usually, however, the underlying macronodular hyperplasia is suspected by the enlargement and nodularity of the remainder of the ipsilateral and contralateral adrenal glands (figure 2).

\section{Imaging the pituitary gland}

MR imaging is the mainstay of pituitary assessment in Cushing's disease. Standard pituitary imaging protocols typically include thin-section $(2$ or $3 \mathrm{~mm}) \mathrm{Tl}$ -

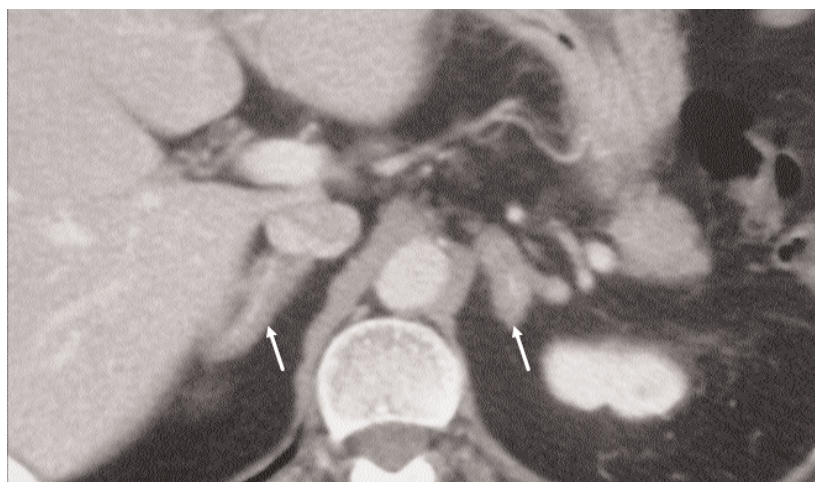

Figure 1. ACTH-dependent smooth hyperplasia of the adrenals. Post-contrast CT of the adrenal glands acquired $60 \mathrm{sec}-$ onds after intravenous contrast administration from a patient with Cushing's syndrome. Both adrenal glands demonstrate smooth hyperplasia and enhancement secondary to an $\mathrm{ACTH}$-producing pituitary adenoma (arrows). 


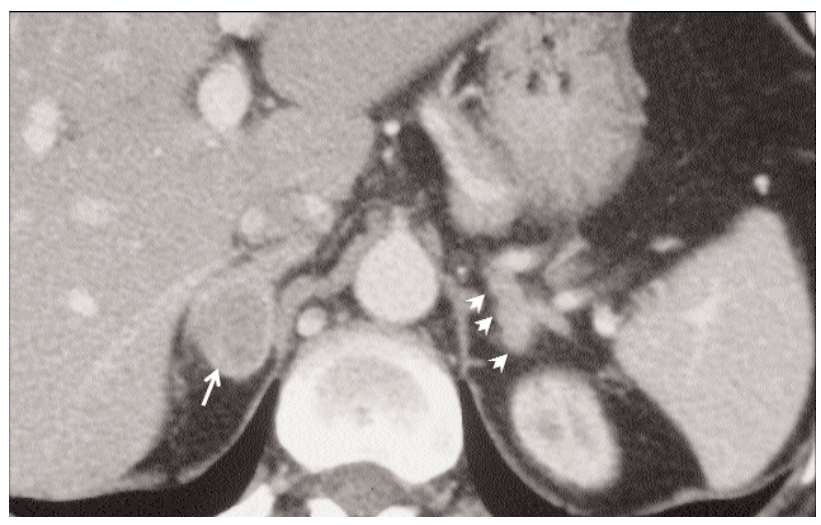

Figure 2. ACTH-dependent macronodular hyperplasia of the adrenals. Post-contrast CT of the adrenal glands acquired 60 seconds after intravenous contrast administration from a patient with Cushing's disease. Both adrenal glands are hyperplastic, with multiple small nodules in the left adrenal gland (arrow heads) and a dominant nodule in the right adrenal gland (arrow). The macronodular hyperplasia was secondary to an ACTH producing pituitary adenoma.

weighted sequences performed in both the coronal and sagittal planes through the pituitary fossa, which are repeated after administration of intravenous gadolinium contrast medium. ACTH-secreting adenomas are most commonly microadenomas (6), which can be identified by their typical MR features; a less than $1 \mathrm{~cm}$ focal area of lesser enhancement, remodelling of the pituitary sella floor and deformity of the gland contour (Ill'n A) (figure 3). Although the sensitivity of enhanced pituitary MRI can be slightly increased by also acquiring a dynamic sequence in the first 1-2 minutes after contrast injection, this technique has not been unequivocally demonstrated to improve the usefulness of MR in Cushing's $(7,8)$.

A minority of cases will have an obvious macroadenoma (greater than $1 \mathrm{~cm}$ ) and assessment of extrasellar extension including chiasmatic compression and cavernous sinus involvement is imperative (Ill'n B). Often, no normal pituitary tissue is visible when a macroadenoma is present (figure 4).

The demonstration of a structural lesion such as a pituitary microadenoma on MR does not establish it as the source of ACTH production, given that incidental microadenomas are present in $10 \%$ of the population (9). Bilateral inferior petrosal sinus sampling (BIPSS) with CRH stimulation is a dynamic investigation to lateralise the site of ACTH production within the pituitary gland and is discussed elsewhere. A number of recent case series of Cushing's disease have demonstrated that BIPSS has a higher overall accuracy at localisation of the ACTH-producing adenoma than pituitary MRI, $88 \%$ vs. $50 \%(10-12)$. This predomi-

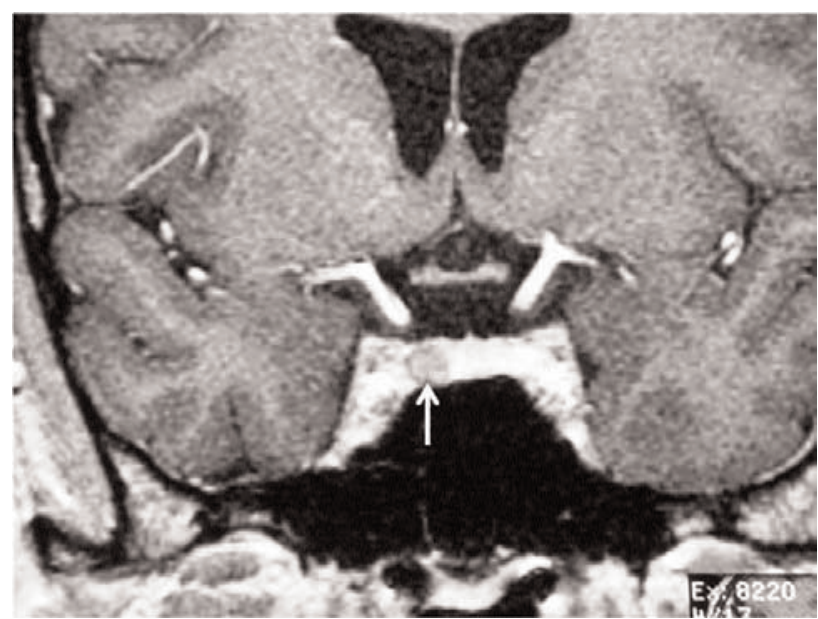

Figure 3. MRI of pituitary microadenoma. Coronal T1weighted post gadolinium enhanced MR of a pituitary microadenoma. There is a $4 \mathrm{~mm}$ area of lesser enhancement in the right side of the gland (arrow), which is of normal size overall. There is no abnormality of the stalk or remodelling of the sellar floor.

nantly reflects the number of false-negative results on MRI. BIPSS is useful to locate a significant number of adenomas (between 53-89\%) in patients where no adenoma is identifiable on MRI, or suggest that the ACTH production is not lateralised to the site of a visible microadenoma $(10,12)$.

Surgical explorations of the pituitary fossa after positive pituitary MRI confirm adenomas in between $81-88 \%$, indicating a false-positive rate of $12-19 \%$ for pituitary MRI $(13,14)$. The highest accuracy for preoperative localisation of a pituitary microadenoma as the source of ACTH production would therefore seem to be a combination of MRI and BIPSS. MRI should be the initial examination, as the finding of a macroadenoma would usually obviate the need for BIPSS. Our current practice is to proceed to BIPSS in those without a macroadenoma, despite a convincing microadenoma on MRI, and we will occasionally even consider a BIPSS in the presence of a macroadenoma if there are unusual features. Pituitary CT scanning is a less sensitive investigation and is now reserved for those patients who cannot safely undertake MR scanning. Nonetheless, acquisition of $1 \mathrm{~mm}$ (or less) axial sections through the pituitary fossa with coronal reconstructions will adequately assess for a macroadenoma and for extension into the suprasellar region.

Pituitary MR also has an important role in the management and surveillance of patients with Nelson's syndrome. In these cases there is evidence of pituitary tumour progression associated with elevated plasma ACTH levels after adrenalectomy. A recent series demonstrated pituitary tumour progression in 


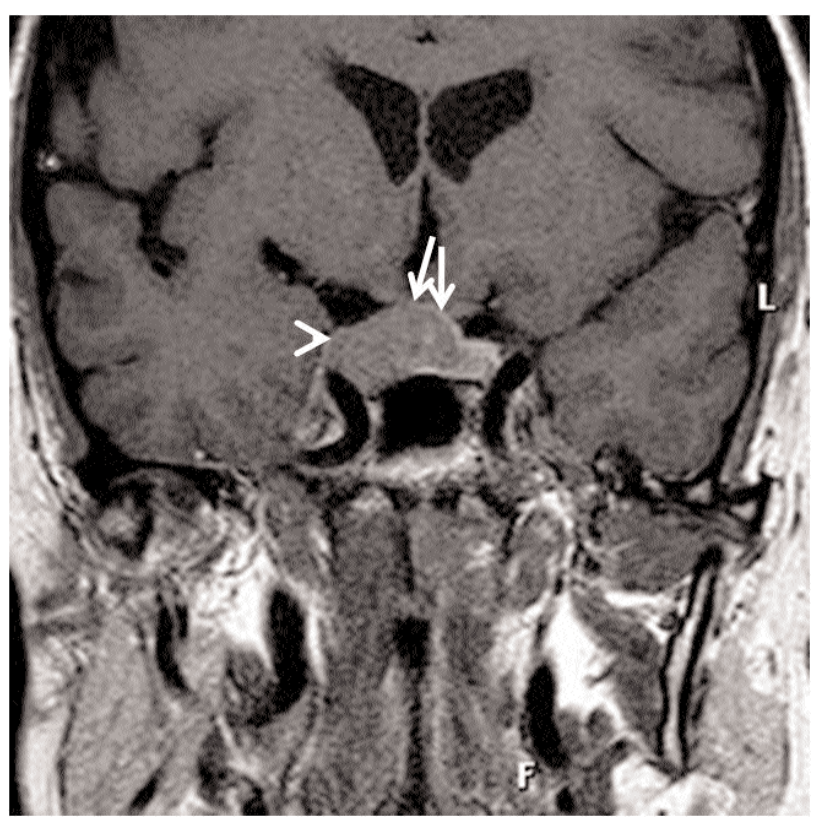

Figure 4. MRI of pituitary macroadenoma. Coronal T1weighted post gadolinium enhanced MR of a pituitary macroadenoma. The adenoma lies in the right side of the sella and extends superiorly to lie in contact with, but not compress, the optic nerves (arrow). There is lateral extension to deform the right cavernous sinus (arrow head). In the absence of visible tumour lateral to the cavernous carotid artery it is unlikely to have invaded the cavernous sinus.

$50 \%$ of 53 patients treated with bilateral adrenalectomy but without pituitary irradiation (15). The MR appearances are those of any progressing macroadenoma with the potential to involve the skull base or the cavernous sinuses, or to compromise the optic pathways (Ill'n 3 ) (figure 5).

\section{Identifying an ectopic ACTH source}

Investigation of patients with 'occult' ectopic ACTH production represents a major challenge since clinical, biochemical and radiological features are often indistinguishable from Cushing's disease (16). The source is usually a neoplasm but rare non-neoplastic causes such mediastinal lipomatosis and possibly congenital adrenal hyperplasia have been reported as causes of ectopic ACTH production $(17,18)$. In our experience, the commonest neoplastic site of origin is the lung (48\%), with the majority of cases being bronchial carcinoid tumours (30\%) (figure 6) and less often a small cell lung cancer (SCLC) (18\%). Other sources of excess ACTH production include neuroendocrine tumours of the thymus, bowel and pancreas, medullary carcinoma of the thyroid, phaeochromocytomas and mesotheliomas. In approximately $12-20 \%$ of patients, despite repeated biochemical and radiological investigations, the source of the ectopic

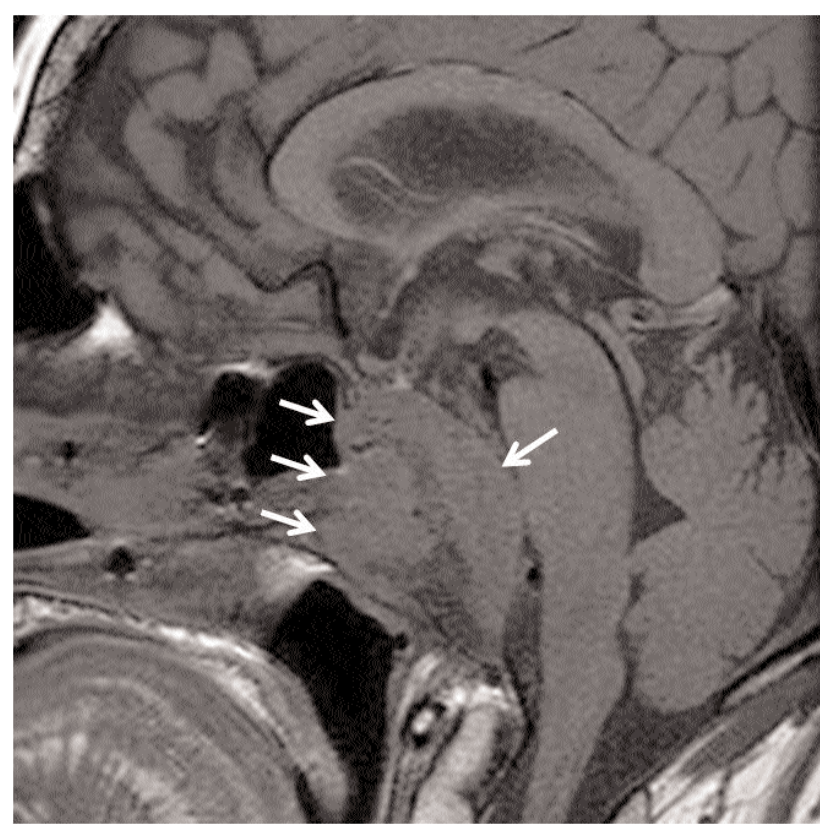

Figure 5. MRI of pituitary macroadenoma. Sagittal unenhanced T1-weighted MR of an invasive pituitary macroadenoma in a patient with Nelson's syndrome. The adenoma has involved the whole of the clivus and much of the sphenoid. The mass bulges posteriorly from the clivus to deform the brainstem (arrows). No supraseller extension is present.

ACTH production remains undiscovered (19). Occult ectopic ACTH syndrome has been defined as ACTHdependent hypercortisolism of greater than 6 months duration without emergence of an obvious cause or source (20).

CT of the chest, abdomen and pelvis with intravenous injection of contrast medium is the most sensitive imaging modality for the identification of the ectopic source. Bronchial carcinoids are small, typically between $3-15 \mathrm{~mm}$ in size and may be difficult to distinguish from granulomas and hamartomas (16). ACTH-producing small cell lung cancers (SCLC) and neuroendocrine tumours of the pancreas and colon have radiological features similar to non-ACTH producing tumours. Thus, in patients with unexplained ectopic ACTH production, all small intrapulmonary lesions should be viewed with suspicion. MRI is useful in resolving equivocal CT findings or where CT is negative and a high index of suspicion persists, particularly for tumours within the abdomen. In the chest, MRI is of limited value in identifying bronchial carcinoids but may be of value in imaging the mediastinum for thymic lesions. In the abdomen, MRI may identify small islet cell tumours of the pancreas not seen on CT. Overall, two large studies have found ${ }^{111}$ In-octreotide scintigra- 
phy and whole body venous sampling generally unhelpful in localising the source of ectopic ACTH $(19,21)$. 18Fluorodeoxyglucose positron emission tomography (FDG PET) has been recently evaluated and shown to be inferior to CT and MRI in the detection of ectopic ACTH sources. The hyperstimulated, hyperplastic adrenal glands also obscure the detection of any ACTH secreting adrenal lesion such as a carcinoma (22). However, PET scanning using ${ }^{11} \mathrm{C}-5 \mathrm{HTP}$ or ${ }^{68} \mathrm{Ga}$-octreotate may have advantages.

\section{ACTH-INDEPENDENT CUSHING'S SYNDROME}

ACTH-independent Cushing's syndrome is due to autonomous primary adrenal pathology producing cortisol. Adrenal adenomas and carcinomas account for $95 \%$ of the cases. Primary pigmented nodular adrenal dysplasia (PPNAD) and ACTH independent macronodular hyperplasia (AIMAH) are responsible for almost all the remainder.

\section{Adrenal adenomas}

Hyperfunctioning ACTH secreting adenomas, which account for up to $65 \%$ of the cases, have imaging features similar to other benign non-hyperfunctioning adrenal adenomas. They are best demonstrated on CT, are usually between $2-7 \mathrm{~cm}$ in size, and have low or soft tissue attenuation usually enhancing after contrast administration. As in our experience 95\% of these hyperfunctioning adenomas are lipid rich, they have non-contrast CT attenuation values of $10 \mathrm{HU}$ or lower (23) (figure 7). MRI also readily demonstrates adrenal adenomas as low homogeneous signal on $\mathrm{Tl}$-weighted images and a signal intensity equivalent or higher than the liver on T2-weighted images. Chemical shift imaging will readily identify the lipid rich adenomas with signal loss on the out-of-phase sequences (23) (figure 8). The remainder of the adrenal gland and the contralateral adrenal are either normal or atrophic due to low circulating ACTH levels (23). Rarely, cortisol producing adenomas may be bilateral or occur simultaneously with PPNAD (24-26). Heterotopic adrenal tissue can be found along the embryological migration path of the adrenal glands and gonadal organs. Although in the majority this is normal accessory adrenal tissue, secretory adenomas causing Cushing's syndrome have been reported (27). These tissue 'rests' may also be responsible for recurrence of adrenal function following bilateral adrenalectomy.

\section{Adrenal carcinoma}

Adrenal carcinomas are rare, with an incidence approximately $0.6-1.67$ cases per million persons per year. The female-to-male ratio is approximately 2.5-3:1. Male patients tend to be older and have a worse overall prognosis than female patients. Female patients are more likely to have an associated endocrine syndrome. Nonfunctional carcinomas are distributed equally between the sexes. Adrenal carcinoma occurs in 2 major peaks: in the first decade of life and again in the fourth to fifth decades. Approximately $75 \%$ of the children with adrenal carcinoma are younger than 5 years. Functioning
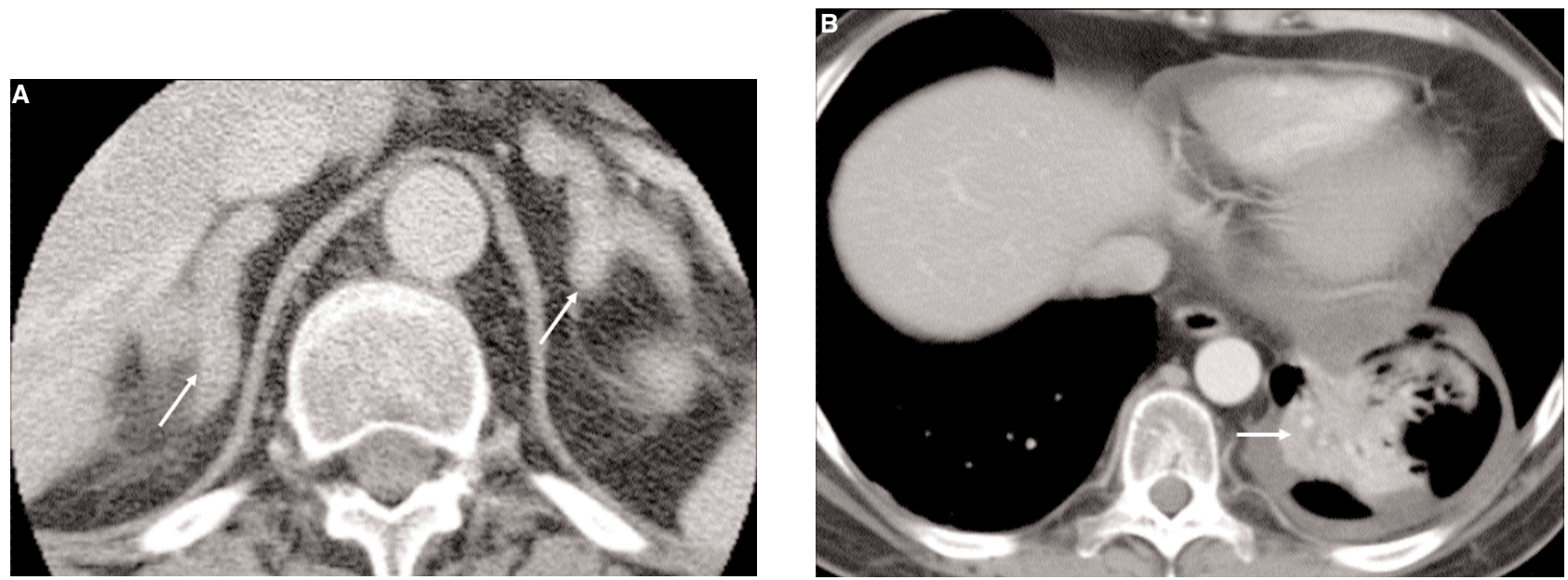

Figure 6. Ectopic ACTH-dependent macronodular hyperplasia of the adrenals. A) Post-contrast CT of the adrenal glands acquired 60 seconds after intravenous contrast administration from a patient with ACTH-dependent Cushing's syndrome with ectopic ACTH production, showing massive smooth bilateral adrenal hyperplasia (arrows). B) Lung window and algorithm of the same patient's CT chest shows a left lower lobe collapse (arrow) suggesting endobronchial obstruction. Bronchoscopy revealed a small ACTH producing carcinoid tumour in the left lobe bronchus. 


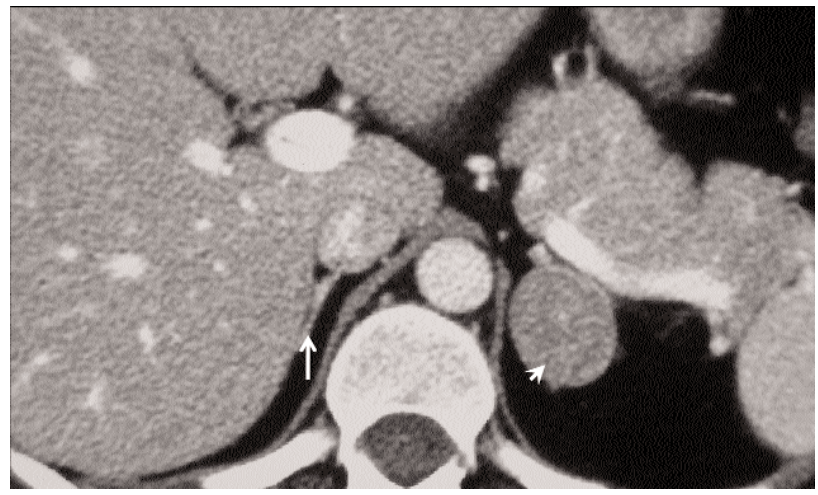

Figure 7. Adrenal adenoma CT. Post-contrast CT of the adrenal glands acquired 60 seconds after intravenous contrast administration showing a left adrenal adenoma (arrow head) in a patient with Cushing's syndrome. The remaining left adrenal and the contralateral right adrenal gland are suppressed and atrophic (arrows). There is fatty change in the liver, which is frequently seen in patients with Cushing's syndrome.
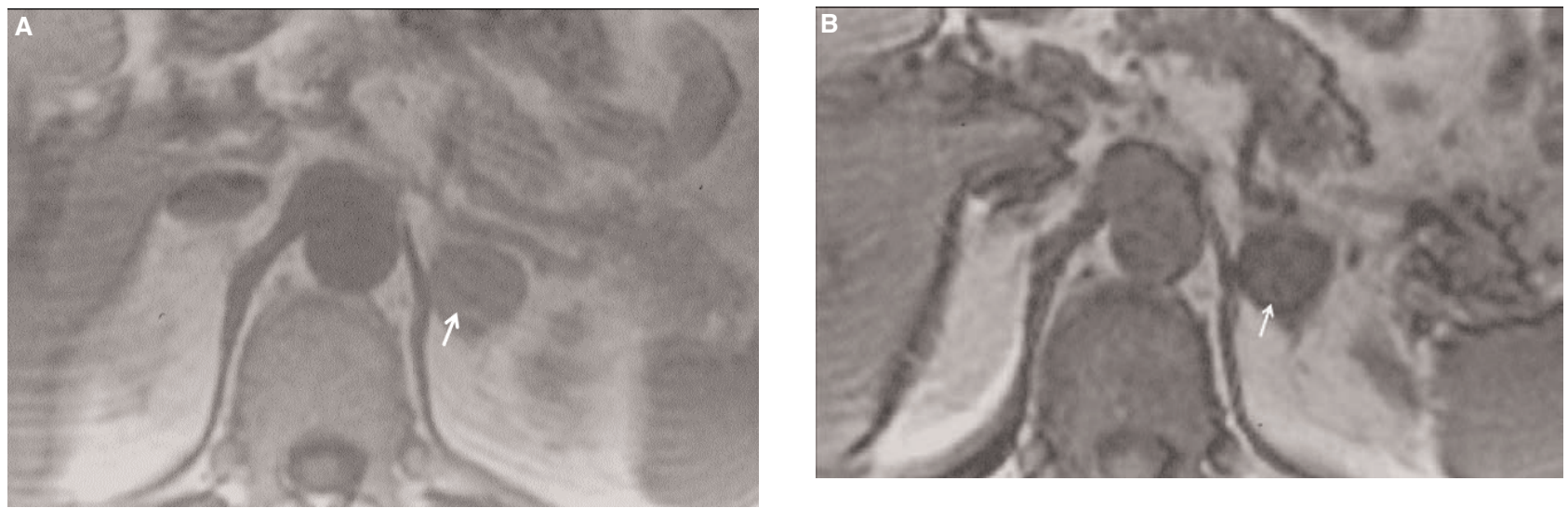

Figure 8. Adrenal adenoma on MRI chemical shift imaging. A) In-phase image from MRI chemical shift imaging demonstrating a left adrenal mass in a patient with ACTH-independent Cushing's syndrome (arrow). B) Out-of-phase image from MRI chemical shift imaging demonstrating the mass losses signal intensity in keeping with a benign lipid containing adenoma (arrow).

tumours are more common in children with resultant Cushing's syndrome or virilisation, while non-functional tumours are more common in adults (23). In adults, $30-40 \%$ of adrenal carcinomas are hyperfunctioning. Hypercortisolism and virilisation are the most common endocrine manifestations although trace amounts of other hormones may be produced. In our series, carcinomas accounted for $27 \%$ of ACTH-independent Cushing's syndrome (24) (figure 9).

CT typically shows a unilateral mass, usually over $6 \mathrm{~cm}$ in size with an inhomogeneous appearance due to necrosis, haemorrhage, fibrosis and calcification. Smaller carcinomas may resemble adenomas. Recent studies combining non-enhanced, delayed-enhancement CT attenuation and percentage of contrast enhancement washout attenuation values at 10 minutes showed adrenal carcinomas all behaved as non-adenomas. Using these criteria adenomas were distinguished from adrenal carcinomas and phaeochromocytomas with a sensitivity and specificity of $100 \%(28,29)$. As with renal tumours, careful assessment of the draining venous structures is essential on imaging together with identification of direct infiltration of adjacent viscera such as the liver, kidney or spleen. Venous invasion occurred in $40 \%$ of our series (23). Multiplanar imaging using MRI or multidetector CT allows better assessment of invasion into adjacent structures, important for surgical planning. Metastases to the liver and lungs are not infrequent. A large mass, high suspicion of malignancy and surrounding invasion preclude laproscopic adrenalectomy or even biopsy, which may be suitable for small unilateral benign adenomas. 


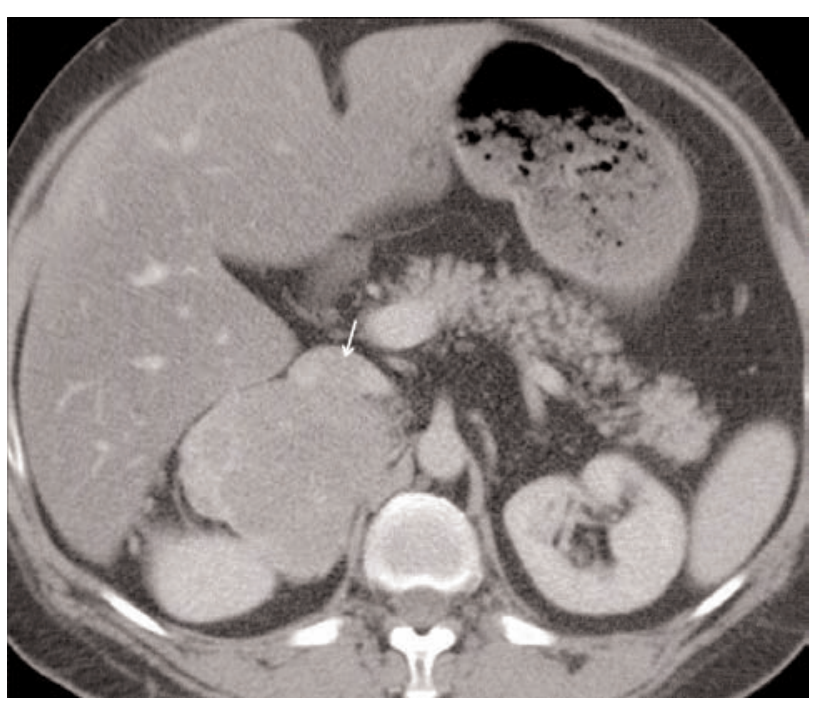

Figure 9. Adrenal carcinoma on CT scanning. Post-contrast $\mathrm{CT}$ of the adrenal glands acquired 60 seconds after intravenous contrast administration showing a large heterogeneous right adrenal mass in a patient with ACTH-independent Cushing's disease. There is direct invasion of the adjacent inferior vena cava (arrow). The appearances are typical for adrenal carcinoma and this was confirmed histologically.

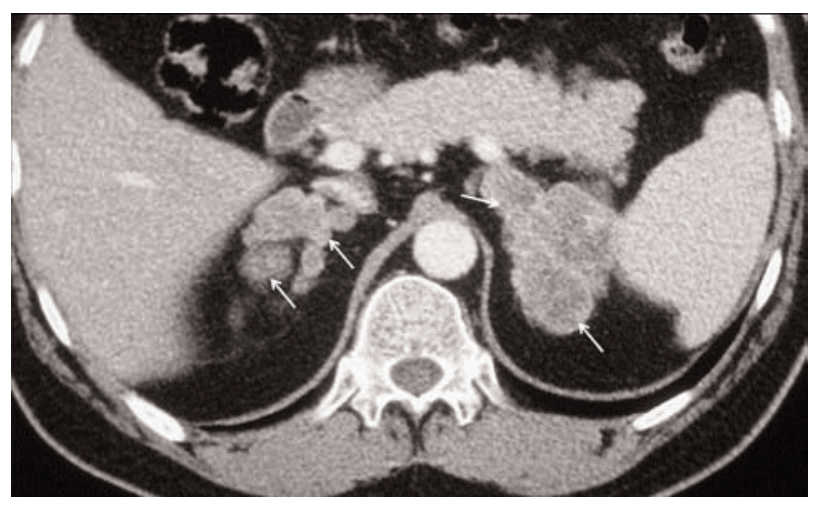

Figure 10. ACTH-independent massive adrenal hyperplasia. Post-contrast CT of the adrenal glands acquired 60 seconds after intravenous contrast administration demonstrating massive nodular hyperplasia of both adrenal glands (arrows). The suppressed ACTH levels distinguish this macronodular hyperplasia from the ACTH-dependent hyperplasia in pituitary adenomas and ectopic ACTH production.

Table 1. Clinical features of primary pigmented nodular adrenocortical disease and ACTH-independent macronodular adrenal hyperplasia.

\begin{tabular}{|c|c|}
\hline PPNAD & AIMAH \\
\hline $\begin{array}{l}\text { Average age } 18 \text { years with slight } \\
\text { female predominance }\end{array}$ & $\begin{array}{l}\text { Average age } 50 \text { years with slight male } \\
\text { predominance }\end{array}$ \\
\hline $\begin{array}{l}\text { Elevated plasma cortisol with loss } \\
\text { of diurnal variation }\end{array}$ & $\begin{array}{l}\text { Elevated plasma cortisol with loss of } \\
\text { diurnal variation }\end{array}$ \\
\hline $\begin{array}{l}\text { No suppression of adrenal cortisol } \\
\text { secretion by dexamethasone, low } \\
\text { and high dose }\end{array}$ & $\begin{array}{l}\text { No suppression of adrenal cortisol } \\
\text { secretion by dexamethasone, low and } \\
\text { high dose } \\
\text { Variable response to ACTH stimulation }\end{array}$ \\
\hline $\begin{array}{l}\text { Normal pituitary sella and pitu- } \\
\text { itary fossa }\end{array}$ & Normal pituitary sella and pituitary fossa \\
\hline
\end{tabular}

Normal or slight nodular adrenal Adrenal nodule size 0.5 to $5.3 \mathrm{~cm}$ hyperplasia, uni or bilateral

$50 \%$ of cases familial and associated with unusual conditions, e.g. Carney complex

\section{Primary pigmented nodular adrenocortical disease (PPNAD)}

This is a rare cause of Cushing's syndrome in infants, children and young adults. There is a female predilection and the associated Cushing's syndrome may be severe. The disease may be familial and is frequently associated with the Carney complex (see below). On imaging, adrenal glands in PPNAD may be normal or minimally hyperplastic with multiple, unilateral or bilateral benign cortical nodules. The adrenal nodules are macroscopically pigmented; the nodules demonstrate lower T1 and T2 signal intensity on MRI compared to surrounding atrophic cortical tissue. The nodules do not normally exceed $5 \mathrm{~mm}$ but in older patients may be $1-2 \mathrm{~cm}$ in diameter (30). Histologically, the adrenal glands are normal in size and weight in up to one-third of the patients. In others, micronodules may be visible and in addition to the multiple pigmented nodules there is atrophy of the intervening cortex due to low circulating ACTH levels. Rarely, 
macronodules $(>1 \mathrm{~cm}$ ) are visible in one or both glands. On imaging, where nodules are $1-2 \mathrm{~cm}$ in size, atrophy of the intervening cortex helps distinguish this from ACTH-dependent hyperplasia. In the absence of a central gradient on petrosal venous sampling and normal cross sectional imaging, a presumptive diagnosis of PPNAD may be assumed by bilateral uptake of 131I-cholesterol scinitigraphy (30), although this is rarely used nowadays. The adrenal uptake of ${ }^{131}$ I-cholesterol analogues confirms an adrenal source of cortisol excess as opposed to ectopic adrenal rests.

\section{ACTH-independent macronodular adrenal hyperplasia (AIMAH)}

ACTH-independent macronodular adrenal hyperplasia is a very rare cause of Cushing's syndrome. It occurs more frequently in males in their 40 s, about 10 years older than the mean age of presentation for Cushing's syndrome and the clinical manifestations of the syndrome tend to be mild. The pathophysiology of AIMAH remains obscure. The imaging appearances of the adrenal glands are striking. They show massive bilateral adrenal enlargement, nodularity and distortion of adrenal contour. Nodules vary in size from $1 \mathrm{~cm}$ to $5.5 \mathrm{~cm}$ and on CT are of low attenuation in keeping with lipid rich adenomas (figure 10). Coronal imaging, either with MDCT reconstruction or $\mathrm{MR}$ imaging, best demonstrate the cranio-caudal extent of the adrenal glands, which frequently extend from the diaphragm to below the renal hila (31). On MRI, nodules are hypointense relative to liver on $\mathrm{Tl}$-weighted images and hyperintense or isointense to liver on T2weighted images. In ACTH-dependent Cushing's syndrome nodules are isointense to liver on T2 images, while in PPNAD nodules are hypointense on both $\mathrm{Tl}$ and $\mathrm{T} 2$-weighted images. On chemical shift imaging, nodules lose signal intensity on outof-phase images due to their high lipid content. Iodine-131-Iodomethylnor-cholesterol (NP-59) scintigraphy shows adrenal uptake. There is controversy regarding the inter-nodular adrenal cortex. This is usually histologically difficult to identify due to the gross nodular distortion of the adrenals. Hyperplastic, normal and atrophic changes have all been reported, and because of this uncertainty the morphology of the inter-nodular cortex is not a criteria for the pathological diagnosis of AIMAH (31). In contrast, the inter-nodular cortex in ACTHdependent macronodular hyperplasia is always hyperplastic.

\section{SYNDROMES ASSOCIATED WITH CUSHING'S SYNDROME}

\section{Carney complex}

The Carney complex was described in 1985 by Carney and colleagues as a complex of myxomas, spotty pigmentation and endocrine overactivity in children and young adults (32). The adrenal endocrinopathies include Cushing's syndrome and increased androgen production resulting in hirsutism. Cushing's syndrome in Carney's complex is ACTH-independent and due to PPNAD. The imaging features of the adrenal gland therefore reflect PPNAD, as described above.

\section{McCune-Albright syndrome}

The classical triad of McCune-Albright syndrome (MAS) consists of polyostotic fibrous dysplasia, caféau-lait skin pigmentation and endocrine dysfunction, frequently seen as precocious puberty, hyperthyroidism, acromegaly, pituitary hyperplasia or adenomas and Cushing's syndrome. The nature of the Cushing's syndrome is unclear. The cortisol levels are elevated, the ACTH levels are low but detectable and there is preservation of some diurnal variation of cortisol production. The pattern is therefore not typical for ACTH dependent or independent disease, suggesting both a central (hypothalamic and pituitary) and autonomous adrenal cause. On imaging the adrenal glands may show nodular hyperplasia (33).

\section{Multiple Endocrine Neoplasia Type 1 (MEN 1)} Multiple endocrine neoplasia type 1 (MENl) is an inherited autosomal dominant endocrine disorder with a very high penetrance. It affects both sexes equally and shows no geographical, racial, or ethnic preference. Cushing's syndrome in MEN 1 may be caused by ACTH secreting pituitary adenomas, ACTH producing carcinoid tumours, functioning adrenal adenomas and carcinomas or adrenal hyperplasia. The incidence of pituitary adenomas in patients with MEN 1 varies from $15-90 \%$ and $3 \%$ of these are ACTH-secreting adenomas (34). Carcinoid tumours are estimated to occur in $10 \%$ of MEN 1 patients and may be asymptomatic. Rarely, thymic, gastric or bronchial carcinoids secrete ACTH and result in Cushing's syndrome (34). Adrenal cortical adenomas and carcinomas have been reported in 30-55\% of MEN 1 patients $(35,36)$ : approximately $10 \%$ of the tumours are ACTH secreting (36). ACTH-independent bilateral diffuse and nodular adrenal hyperplasia has been reported in up to $35 \%$ of patients with MENI 
but the underlying aetiology of this hyperplasia is unclear. It has been observed in all these patients, there are concurrent pancreatic lesions and it is postulated the pancreatic lesions secrete ACTH-like polypeptides stimulating the adrenal glands. In these patients the symptoms of Cushing's syndrome are mild (35).

\section{REFERENCES}

1. Trainer PJ, Besser GM. Cushing's syndrome. In: Besser GM, Thorner MO (eds). Comp Clin Endocrinol. $3^{\text {rd }}$ ed. Edinburgh: Mosby, 2002. pp. 193-202.

2. Bickler SW, McMahon TJ, Campbell JR, Mandel S, Piatt JH, Harrison MW. Preoperative diagnostic evaluation of children with Cushing's syndrome. J Pediatr Surg 1994;29(5):671-6.

3. Sohaib SA, Hanson JA, Newell-Price JD, Trainer PJ, Monson JP, Grossman AB, et al. CT appearance of the adrenal glands in adrenocorticotrophic hormone-dependent Cushing's syndrome. AJR Am J Roentgenol 1999;172(4):997-1002.

4. Doppman JL, Miller DL, Dwyer AJ, Loughlin T, Nieman L, Cutler GB, et al. Macronodular adrenal hyperplasia in Cushing disease. Radiology 1988;166(2):347-52.

5. Smals AG, Pieters GF, van Haelst UJ, Kloppenborg PW. Macronodular adrenocortical hyperplasia in long-standing Cushing's disease. J Clin Endocrinol Metab 1984;58(1):25-31.

6. Woo YS, Isidori AM, Wat WZ, Kaltsas GA, Afshar F, Sabin I, et al. Clinical and biochemical characteristics of adrenocorticotropin-secreting macroadenomas. J Clin Endocrinol Metab 2005;90(8):4963-9.

7. Bartynski WS, Lin L. Dynamic and conventional spin-echo MR of pituitary microlesions. AJNR Am J Neuroradiol 1997;18(5):965-72.

8. Tabarin A, Laurent F, Catargi B, Olivier-Puel F, Lescene R, Berge $\mathrm{J}$, et al. Comparative evaluation of conventional and dynamic magnetic resonance imaging of the pituitary gland for the diagnosis of Cushing's disease. Clin Endocrinol (Oxf) 1998;49(3):293-300.

9. Buurman H, Saeger W. Subclinical adenomas in postmortem pituitaries: classification and correlations to clinical data. Eur J Endocrinol 2006;154(5):753-8.

10. Kaskarelis IS, Tsatalou EG, Benakis SV, Malagari K, Komninos I, Vassiliadi D, et al. Bilateral inferior petrosal sinuses sampling in the routine investigation of Cushing's syndrome: a comparison with MRI. AJR Am J Roentgenol 2006;187(2):562-70.

11. Lienhardt A, Grossman AB, Dacie JE, Evanson J, Huebner A, Afshar $F$, et al. Relative contributions of inferior petrosal sinus sampling and pituitary imaging in the investigation of children and adolescents with ACTH-dependent Cushing's syndrome. J Clin Endocrinol Metab 2001;86(12):5711-4.

12. Booth GL, Redelmeier DA, Grosman H, Kovacs K, Smyth HS, Ezzat S. Improved diagnostic accuracy of inferior petrosal sinus sampling over imaging for localizing pituitary pathology in patients with Cushing's disease. J Clin Endocrinol Metab 1998;83(7):2291-5.

13. Testa RM, Albiger N, Occhi G, Sanguin F, Scanarini M, Berlucchi $\mathrm{S}$, et al. The usefulness of combined biochemical tests in the diagnosis of Cushing's disease with negative pituitary magnetic resonance imaging. Eur $\mathbf{J}$ Endocrinol 2007; 156(2):241-8.

14. Salenave S, Gatta B, Pecheur S, San-Galli F, Visot A, Lasjaunias $P$, et al. Pituitary magnetic resonance imaging findings do not influence surgical outcome in adrenocorticotropinsecreting microadenomas. J Clin Endocrinol Metab 2004;89(7):3371-6.
15. Assie G, Bahurel H, Coste J, Silvera S, Kujas M, Dugue MA, et al. Corticotroph tumor progression after adrenalectomy in Cushing's Disease: A reappraisal of Nelson's Syndrome. J Clin Endocrinol Metab 2007:92(1):172-9.

16. Vincent JM, Trainer PJ, Reznek RH, Marcus AJ, Dacie JE, Armstrong $P$, et al. The radiological investigation of occult ectopic ACTH-dependent Cushing's syndrome. Clin Radiol 1993;48(1):11-7.

17. Drasin GF, Lynch T, Temes GP. Ectopic ACTH production and mediastinal lipomatosis. Radiology 1978;127(3):610.

18. Georgitis WJ. Clinically silent congenital adrenal hyperplasia masquerading as ectopic adrenocorticotropic hormone syndrome. Am J Med 1986;80(4):703-8.

19. Ilias I, Torpy DJ, Pacak K, Mullen N, Wesley RA, Nieman LK. Cushing's syndrome due to ectopic corticotropin secretion: twenty years' experience at the National Institutes of Health. J Clin Endocrinol Metab 2005;90(8):4955-62.

20. Findling JW, Raff H. Cushing's Syndrome: important issues in diagnosis and management. J Clin Endocrinol Metab 2006;91(10):3746-53.

21. Isidori AM, Kaltsas GA, Pozza C, Frajese V, Newell-Price J, Reznek RH, et al. The ectopic adrenocorticotropin syndrome: clinical features, diagnosis, management, and long-term follow-up. J Clin Endocrinol Metab 2006;91(2):371-7.

22. Pacak K, Ilias I, Chen CC, Carrasquillo JA, Whatley M, Nieman LK. The role of [(18)F]fluorodeoxyglucose positron emission tomography and [(111)In]-diethylenetriaminepentaacetate-D-Phe-pentetreotide scintigraphy in the localization of ectopic adrenocorticotropin-secreting tumors causing Cushing's syndrome. J Clin Endocrinol Metab 2004;89(5):2214-21.

23. Rockall AG, Babar SA, Sohaib SA, Isidori AM, Diaz-Cano S, Monson JP, et al. CT and MR imaging of the adrenal glands in ACTH-independent cushing syndrome. Radiographics 2004;24(2):435-52.

24. Dinneen SF, Carney JA, Carpenter PC, Grant CS, Young WF Jr. ACTH-independent Cushing's syndrome: bilateral cortisolproducing adrenal adenomas. Endocr Pract 1995;1(2):7781.

25. Tung SC, Wang PW, Huang TL, Lee WC, Chen WJ. Bilateral adrenocortical adenomas causing ACTH-independent Cushing's syndrome at different periods: a case report and discussion of corticosteroid replacement therapy following bilateral adrenalectomy. J Endocrinol Invest 2004;27(4):375-9.

26. Nomura K, Saito $H$, Aiba M, lihara M, Obara T, Takano K. Cushing's syndrome due to bilateral adrenocortical adenomas with unique histological features. Endocr J 2003;50(2):155-62.

27. Ayala AR, Basaria S, Udelsman R, Westra WH, Wand GS. Corticotropin-independent Cushing's syndrome caused by an ectopic adrenal adenoma. J Clin Endocrinol Metab 2000;85(8):2903-6.

28. Szolar DH, Korobkin M, Reittner P, Berghold A, Bauernhofer $\mathrm{T}$, Trummer $\mathrm{H}$, et al. Adrenocortical carcinomas and adrenal pheochromocytomas: mass and enhancement loss evaluation at delayed contrast-enhanced CT. Radiology 2005;234(2):479-85.

29. Slattery JM, Blake MA, Kalra MK, Misdraji J, Sweeney AT, Copeland PM, et al. Adrenocortical carcinoma: contrast washout characteristics on CT. AJR Am J Roentgenol 2006;187(1):W21-4.

30. Doppman JL, Travis WD, Nieman L, Miller DL, Chrousos GP, Gomez MT, et al. Cushing syndrome due to primary pigmented nodular adrenocortical disease: findings at CT and MR imaging. Radiology 1989;172(2):415-20.

31. Lieberman SA, Eccleshall TR, Feldman D. ACTH-independent massive bilateral adrenal disease (AIMBAD): a subtype of Cushing's syndrome with major diagnostic and therapeutic implications. Eur J Endocrinol 1994;131(1):67-73.

32. Carney JA, Gordon H, Carpenter PC, Shenoy BV, Go VL. The complex of myxomas, spotty pigmentation and endocrine overactivity. Medicine (Baltimore) 1985;64:270-83. 
33. Danon M, Robboy SJ, Kim S, Scully R, Crawford JD. Cushing syndrome, sexual precocity, and polyostotic fibrous dysplasia (Albright syndrome) in infancy. J Pediatr 1975;87(6 Pt 1):917-21.

34. Marini F, Falchetti A, Del Monte F, Sala SC, Gozzini A, Luzi E, et al. Multiple endocrine neoplasia type 1. Orphanet J Rare Dis 2006; $1: 38$

35. Skogseid B, Larsson C, Lindgren PG, Kvanta E, Rastad J, Theodorsson $\mathrm{E}$, et al. Clinical and genetic features of adrenocortical lesions in multiple endocrine neoplasia type 1. J Clin Endocrinol Metab 1992;75(1):76-81.

36. Waldmann J, Bartsch DK, Kann PH, Fendrich V, Rothmund M Langer P. Adrenal involvement in multiple endocrine neoplasia type 1: results of 7 years prospective screening. Langenbecks Arch Surg 2007;392(4):437-43. Epub 2007 Jan 19
Address for correspondence:

Anju Sahdev

Consultant Radiologist

Department of Diagnostic Imaging

St. Bartholomew's Hospital

West Smithfield

London ECIA 7BE

Fax: +44 2076018868

E-mail: anju.sahdev@bartsandthelondon.nhs.uk 